\title{
Oftalmología en imágenes
}

\section{Ophthalmology in images}

\section{Andreas Di Luciano ${ }^{1 *}$, Caroline Tsimi y Thomas Johnson ${ }^{3,4}$}

${ }^{1}$ Flying Eye Hospital, Orbis International, Nueva York, Estados Unidos; ${ }^{2}$ Hospital Central, Yaounde, Camerún; ${ }^{3}$ Universidad de Miami, Miami, Estados Unidos; ${ }^{4}$ Bascom Palmer Eye Institute, Miami, Estados Unidos

Un paciente de 50 años, sin antecedentes médicos relevantes, fue atacado con un cuchillo y recibió una lesión en la órbita izquierda (Fig. 1). El paciente fue trasladado a la sala de emergencias.

En la evaluación inicial, el paciente tenía un examen neurológico normal y estabilidad hemodinámica.

El examen oftalmológico mostró que el objeto afilado estaba ubicado en la región medial de la órbita izquierda. El tejido circundante estaba edematoso, lo que dificultaba la evaluación de ese ojo. El ojo derecho (OD) era normal.

Una tomografía computarizada de la órbita mostró un cuerpo extraño orbitario radiopaco situado entre el globo ocular y la pared medial de la órbita, con una fractura con involucro del hueso etmoidal en la órbita izquierda (Figs. 2 y 3 ).

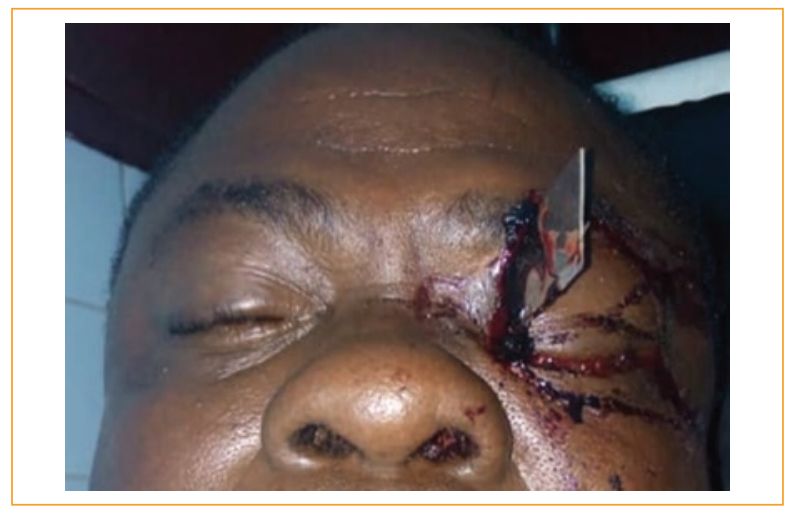

Figura 1. Vista frontal del paciente. Lesión de la órbita izquierda. Cuerpo extraño reconocido como un cuchillo.

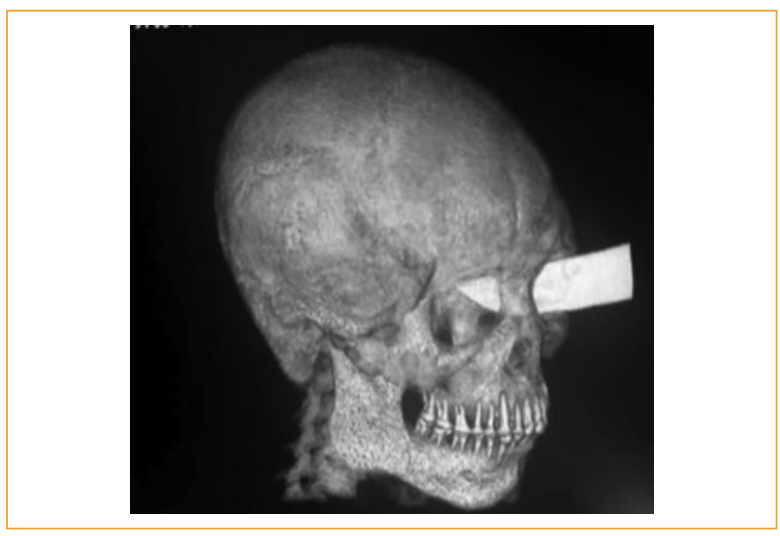

Figura 2. Tomografía computarizada de la órbita. Cuerpo extraño en la órbita izquierda.

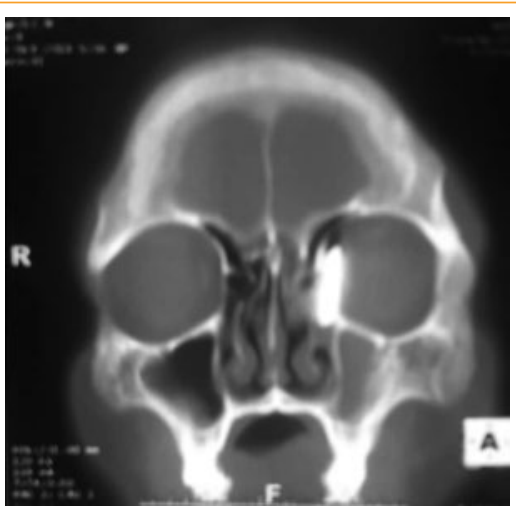

Figura 3. Tomografía computarizada de la órbita, corte coronal. Se observa un cuerpo extraño intraorbitario radiopaco. Se encuentra entre el globo ocular y la pared medial de la órbita.
Correspondencia:

${ }^{*}$ Andreas Di Luciano

E-mail: andreasdilu@gmail.com
Disponible en internet: 02-01-2020 Rev Mex Oftalmol. 2020;94(1):51-52

www.rmo.com.mx 0187-4519/C 2019 Sociedad Mexicana de Oftalmología. Publicado por Permanyer. Éste es un artículo open access bajo la licencia CC BY-NC-ND (http://creativecommons.org/licenses/by-nc-nd/4.0/). 
El cuerpo extraño fue extirpado bajo anestesia general, suturando y reparando los tejidos por planos. En la exploración, no hubo evidencia de penetración del cuerpo extraño en el globo ocular. El paciente recibió analgésicos y antibióticos después del procedimiento, con buena evolución a las $48 \mathrm{~h}$.

En ese momento, su CV era de 20/40 en el OD y de 20/50 en el ojo siniestro. La exploración del OS reveló un segmento anterior normal, pupilas reactivas con reflejo pupilar normal, así como fondo de ojo normal. Los campos visuales no mostraron alteraciones. Solo había una ligera limitación a la aducción del ojo ipsilateral.

\section{Responsabilidades éticas}

Protección de personas y animales. Los autores declaran que para esta investigación no se han realizado experimentos en seres humanos ni en animales.

Confidencialidad de los datos. Los autores declaran que han seguido los protocolos de su centro de trabajo sobre la publicación de datos de pacientes.

Derecho a la privacidad y consentimiento informado. Los autores han obtenido el consentimiento informado de los pacientes y/o sujetos referidos en el artículo. Este documento obra en poder del autor de correspondencia. 